\title{
The European Union's Position in Global Foreign Direct Investment Flows and Stocks: Institutional Attempts to Improve It
}

\author{
Janina Witkowska (iD https://orcid.org/0000-0002-8698-4623 \\ Ph.D., Full Professor at the Institute of Economics \\ Faculty of Economics and Sociology, University of Lodz, Lodz, Poland \\ e-mail: janina.witkowska@uni.lodz.pl
}

\begin{abstract}
Global flows of foreign direct investment (FDI) have slowed down in recent years, which particularly affected developed countries, including those in the European Union (EU). A general decrease in capital circulation in the form of FDI between the EU and the rest of the world has been observed. The aim of this paper is to assess the changes in the EU's position in global FDI flows and stocks and to discuss attempts made by EU institutions and the EU member states to improve this position. The EU can use the common investment policy to strengthen its investment position. The EU acquired the competence to conduct this policy based on the Lisbon Treaty, while its actual shape was determined in practice. Improving the EU's position in global FDI flows requires agreements regarding foreign investment, concluded at the EU level with other countries and integration groupings. Ensuring national treatment of investors before and after investing is important, as are solutions used for investor protection, investor-state-dispute-settlements (ISDS), and the use of investment project screening to protect strategic sectors of the EU economy. The EU investment policy can mitigate the effects of slowing down FDI flows, create a more favorable climate for outgoing FDI, and protect vital interests for FDI coming into the EU from third countries.
\end{abstract}

Keywords: foreign direct investment (FDI), European Union, investment policy

JEL: F2, F15, F21 


\section{Introduction}

Global foreign direct investment (FDI) flows have shown limited growth since 2008 as a result of different determinants. The underlying FDI trend has averaged only 1 percent growth this decade, compared with 8 percent between 2000 and 2007, and more than 20 percent before 2000 (UNCTAD 2019, p. 5). The UNCTAD report points to the declining rates of return on FDI, increasingly asset-light forms of investment, and the less favorable climate as key drivers for the above-mentioned slowdown in FDI. The underlying trend was combined with long-term changes in geographical structures, both of global FDI flows and stocks. FDI flows to developed economies have reached their lowest level since 2004.

The European Union (EU), as a grouping, experienced a decline in FDI flows as well, which was determined by both external and internal factors. The Lisbon Treaty gives the EU's institutions new external competences, including FDI into the common trade policy. The EU has encountered some obstacles in introducing this provision of the Treaty. Nevertheless, the EU institutions have undertaken some measures related to FDI, which might have some impact on its position in the global economy in this field.

This paper aims to assess the changes in the EU's position in global FDI flows and stocks and to discuss attempts undertaken by EU institutions and the EU member states to improve this position. The hitherto worsening of the EU position in question can be analyzed in the context of a new phenomenon that has been observed in the world economy, namely de-globalization. This has been discussed in the literature (e.g., Della Posta 2018; Primo Braga 2018). However, analyzing the EU's position in global FDI flows and stocks in comparison with the positions of other integration groupings constitutes a new approach and provides a basis for a comparative assessment of the changing positions of the global leaders in this field. Furthermore, the analysis and the evaluation of the EU's common investment policy instruments give a chance to discuss some aspects of their effectiveness. Hence, the existing research gap can be filled to some extent.

The UNCTAD and Eurostat statistics databases were used to analyze and evaluate the changes in global FDI flows and stocks as well as between the EU and the third countries and integration groupings. The official information on the EU's policy towards foreign investment and independent analyses were used as a reference in the paper. 


\section{The position of the European Union in global foreign direct investment flows}

Global capital flows in the form of foreign direct investment (FDI) have slowed down in the last decade, as outlined in the introduction. In 2018, the global inflows of FDI decreased and reached USD 1.3 trillion, i.e., $13 \%$ less than in the previous year (UNCTAD 2019, p. 1). It was the third year in a row in which a decrease in these flows was recorded. In addition to the decline in FDI flows, there were also other symptoms in the world economy (in the sphere of trade, financial globalization) that allowed researchers to ask questions about whether the peak globalization had been reached (Primo Braga 2018).

According to UNCTAD estimates, the decline in FDI flows in 2018 was due to the large-scale repatriation of foreign revenues accumulated by transnational corporations originating in the USA. It was a reaction to the tax reform introduced in the USA in 2017. The decline in FDI flows in 2018 would have been higher if not for the growing value of mergers and acquisitions taking place in the second half of the year (UNCTAD 2019, p. 1). Figure 1 presents the trends in global FDI inflows in 2008-2018.

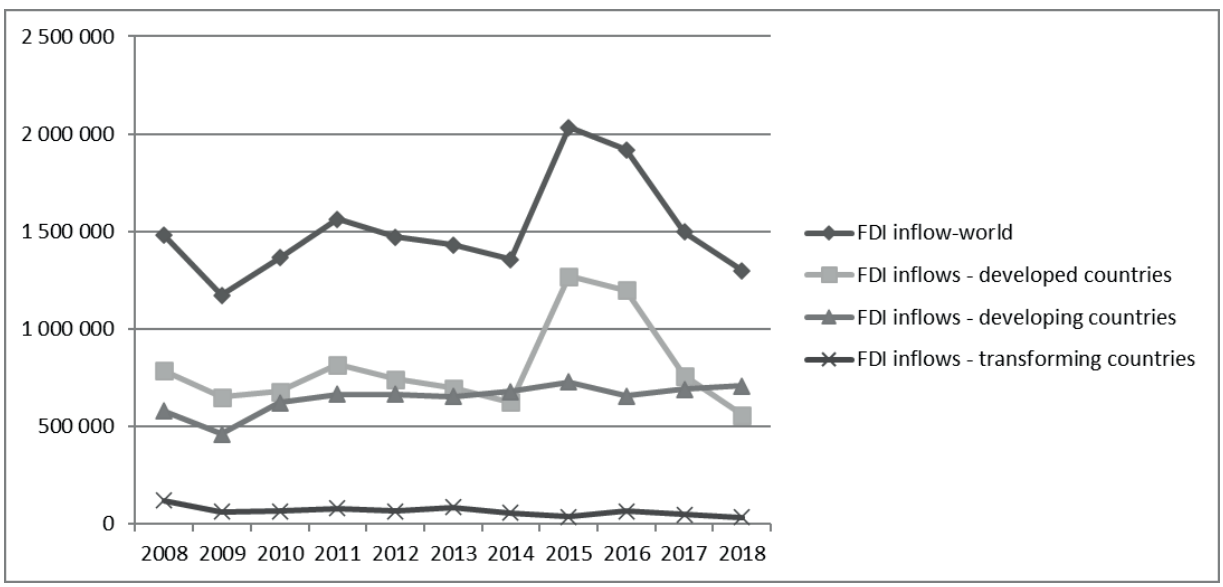

Figure 1. Foreign direct investment inflows, world and groups of countries, 2008-2018, USD million Source: UNCTAD database (a) and own elaboration.

The preliminary data for 2019 for FDI flows in the global economy indicate a decrease of $1 \%$ from the revised global volume for 2018. However, the moderate or even marginal increase in FDI flows forecasted for 2020 (UNCTAD 2020, pp. 1-2) may not be achievable due to the consequences of the COVID-19 pandemic in the global economy.

The geographical structure of global FDI streams by the main groups of host countries indicates changes taking place in the longer term. FDI inflows to developed countries amounted to USD 556.8 billion in 2018, the lowest since 2004. FDI inflows 
to Europe decreased by half, and several European countries (Switzerland, Ireland, Norway) recorded negative values due to the repatriation of funds by US transnational corporations. FDI inflows to Great Britain decreased, which was related to both the behavior of American investors and the ongoing process of Britain leaving the EU. The US also experienced reduced FDI inflows due to a $1 / 3$ decrease in mergers and acquisitions. Australia, on the other hand, had record FDI inflows (USD 60 billion) as foreign subsidiaries reinvested USD 25 billion of profits in the economy (UNCTAD 2019, p. IX, 212). Preliminary data for 2019 show that total FDI inflows to developed countries decreased by another $6 \%$ compared to 2018 (UNCTAD 2020, p. 1).

Developing countries received investments of USD 706 billion in 2018, i.e., about USD 150 billion more than all developed countries. It meant that the share of developing countries in global FDI inflows was 54\%, a record share. At the same time, FDI inflows to developing countries remained stable, showing a slight increase, i.e., by $2 \%$ (UNCTAD 2019, pp. IX, 2, 212, and own calculations). According to preliminary data, FDI inflows to developing countries in 2019 remained unchanged compared to the previous year (UNCTAD 2020, p. 2).

Figure 2 shows FDI inflows to major integration groupings in the global economy.

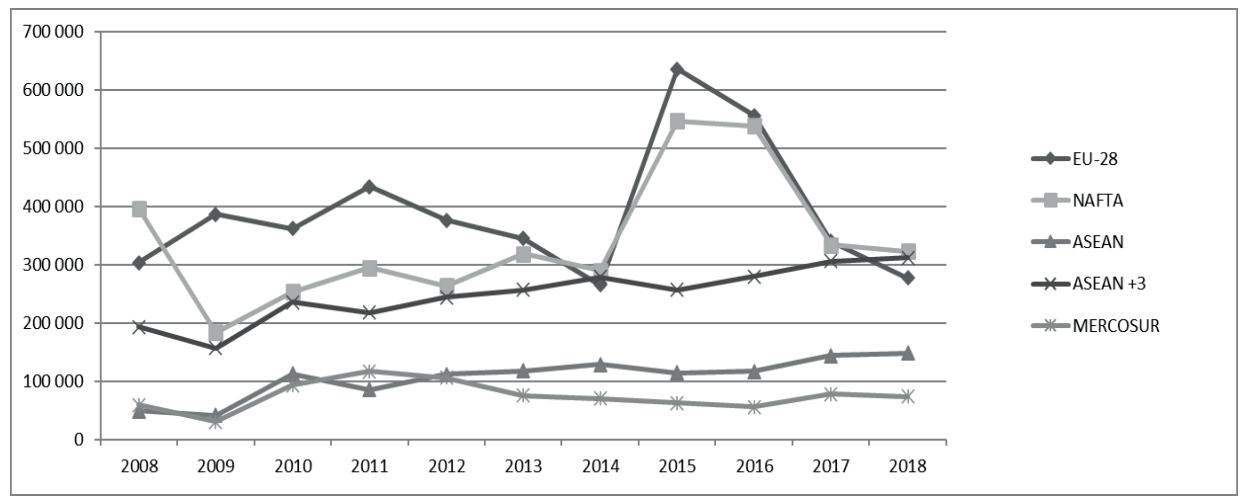

Figure 2. Foreign direct investment inflows to EU-28, NAFTA, ASEAN, ASEAN+3, Mercosur, 2008-2018, USD million

Source: UNCTAD database (a) and own elaboration.

UNCTAD data indicate that four analyzed groups jointly absorb $63 \%$ of the annual global FDI inflows. Two groups, i.e., the EU-28 and NAFTA, still attract more foreign investment than the other two analyzed groups, i.e., ASEAN and Mercosur. For the EU-28 and NAFTA, the trends are generally consistent with those observed in the global economy. However, the EU-28 is losing its investment attractiveness, while ASEAN is gradually gaining. If we include ASEAN+3 in the analysis, it turns out that EU-28, NAFTA, and ASEAN+3 take an almost equal position in global FDI capital inflows. However, the balance that emerged in 2018 is extremely fragile. FDI inflows to ASEAN +3 and ASEAN showed a relatively stable growing trend in the analyzed period. In contrast, inflows to EU-28 
and NAFTA were subject to significant fluctuations in the last ten years. Mercosur, on the other hand, is unable to regain its position achieved after the 2008 crisis when inflows of over USD 100 billion to this grouping were recorded.

A comparison of the analyzed integration groupings in terms of their involvement in foreign direct investment indicates that FDI outflows from the EU-28 changed quite rapidly and did not reach the pre-crisis level throughout the entire analyzed period. In 2018, these streams equaled in absolute terms the FDI outflows from ASEAN+3. It is further evidence of a shift of the focus in this sphere of the global economy towards Asia. Although this process is mainly a result of the investment expansion of China and South Korea, the participation of ASEAN member countries in foreign direct investment flows is also visible. The drastic collapse of outflows from NAFTA seems to be reversible after the change in the US policy towards foreign investment.

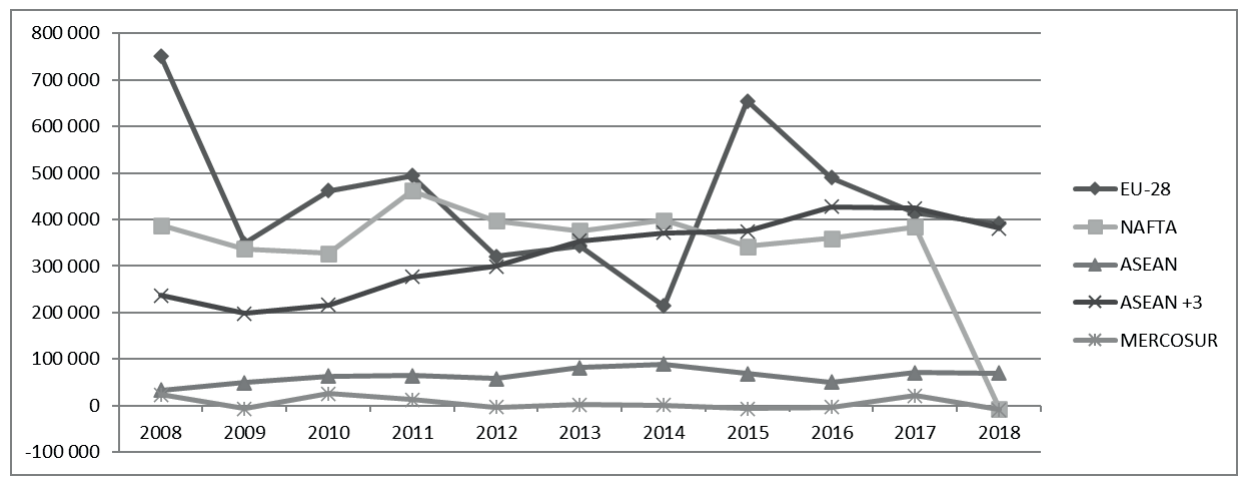

Figure 3. Foreign direct investment outflows from EU-28, NAFTA, ASEAN, ASEAN+3, Mercosur, 2008-2018, USD million

Source: UNCTAD database (a) and own elaboration.

The above statistical analysis of FDI flows in the global economy confirms the slowdown, which has been going on for four years. The cross-section of groups of countries, regions, and groupings revealed the strengthening of Asia, but also, in this case, a slight decrease in FDI outflows was recorded in 2018.

According to UNCTAD assessments, key factors that affect the long-term slowdown of global FDI capital flows include (UNCTAD 2019, pp. 5-6; UNCTAD 2020, p. 2):

- decreasing rates of return on foreign direct investment,

- increasing investor involvement abroad in elusive assets and the so-called non-proprietary forms of investments (e.g., licensing, production contracting),

- a less favorable investment climate, associated with high geopolitical risk and a shift towards protectionist policies.

The assessment of the EU's investment position requires taking into account its shares in global FDI inward and outward stocks. In 2018, these shares were $31 \%$ and $37 \%$, respectively. (UNCTAD 2019, p. 216, and own calculations). In the case of FDI stocks, both inward and outward, the EU's investment position increased in absolute 
terms by about four times compared to 2000. In relative terms, the EU's share did not change in the case of FDI inward stocks, even though the EU expanded by 13 new member countries during this period. On the other hand, the EU's share in FDI outward stocks decreased by 2 percentage points (in 2000, this share was 39\%) (UNCTAD 2019 , p. 216, and own calculations).

\section{Characteristics of the European Union's FDI inflows and outflows}

A more detailed analysis of the volume of annual EU FDI inflows and outflows shows that these flows decreased in absolute terms after the global financial crisis. Despite some positive changes, these flows did not regain the level of 2007. In 2018, they constituted only about $1 / 3$ of the value of flows from before the crisis (UNCTAD database (b) and own calculations), as shown in Figure 4. Factors that affect the situation in global FDI flows also affected the EU's position as a whole. Like other developed countries, it experienced a further decline in FDI inflows in 2016-2018. FDI inflows to the EU decreased by $18.5 \%$ in 2018 compared to the previous year. In contrast, FDI outflows decreased by over 5\% (UNCTAD database (b), and own calculations). Preliminary data for 2019 indicate a further decline in FDI inflows to the EU, i.e., by 15\%, which had a negative impact on the position of all developed countries (UNCTAD 2020, p. 3).

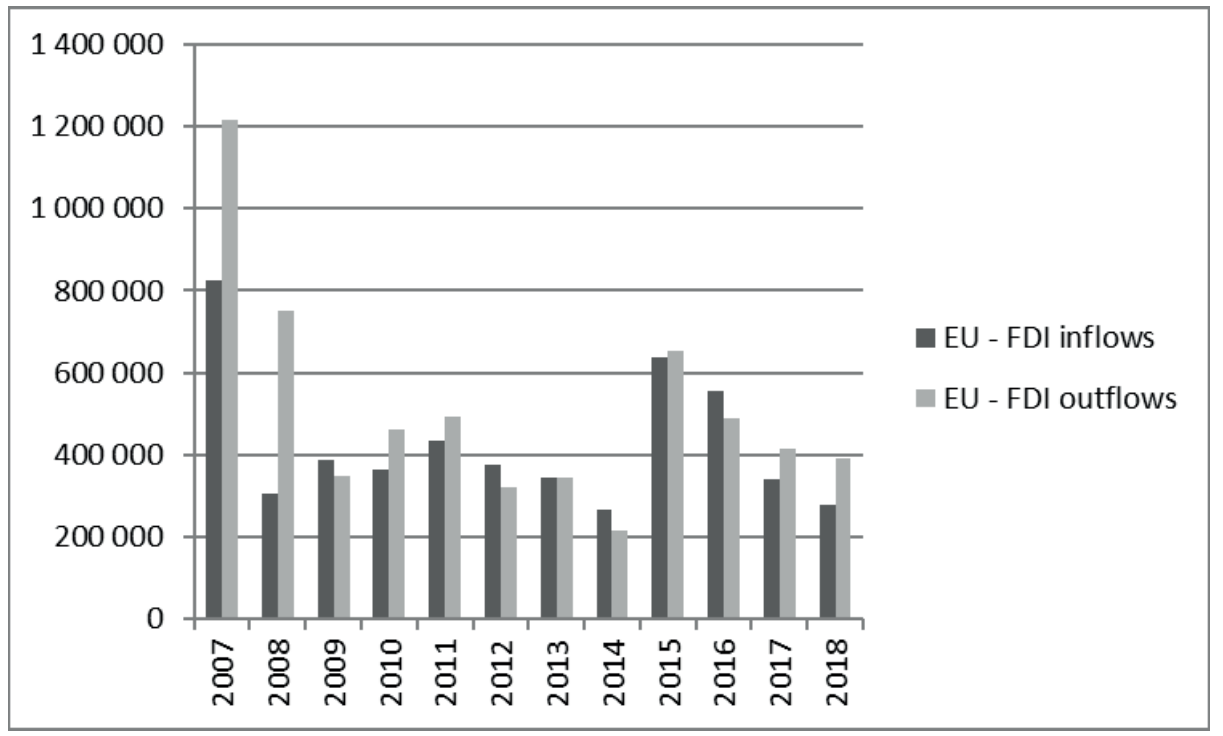

Figure 4. EU FDI inflows and outflows, 2007-2018, USD million Source: UNCTAD database (b). 
Compared to other regions in the global economy, FDI inflows to the EU dropped dramatically. In absolute terms, they amounted to only USD 278 billion in 2018, accounting for slightly above $1 / 5$ of global FDI flows and less than $50 \%$ of FDI inflows to highly developed countries. Compared to the FDI inflows to developing countries, they were 2.5 times lower, and to developing Asia, almost two times lower (UNCTAD 2019 , pp. 212-215, and own calculations).

The situation of individual EU member states in terms of FDI inflows remained varied. Half of them experienced a decline in FDI inflows in 2018, and two member states, Ireland ( -66.3 billion USD) and Luxembourg ( -5.6 billion USD), recorded divestments. The division into countries that experienced an increase in FDI inflows and countries with a decline in FDI did not follow the division into "old" and "new" member countries. However, among the ten EU member states with the highest FDI inflows in 2018, in addition to the "old" member countries, there were only two "new" member countries, i.e., Poland and Czechia. In turn, the most significant FDI outflows occurred in France, Germany, the Netherlands, Great Britain, and Spain. Three countries (Cyprus, Denmark, and Malta) showed divestments in that year (UNCTAD 2019, pp. 212-215 and own calculations). The share of 13 "new" member countries in the total FDI inflows to the EU was $17.6 \%$ in 2018. At the same time, these countries had a marginal share in total FDI outflows from the EU - 2.6\% in 2018 (UNCTAD 2019, p. 212, and own calculations).

According to Eurostat assessments, FDI flows between the EU as a grouping and the rest of the world in 2018, i.e., excluding intra-EU flows, indicate a general decrease in the circulation of this capital between the EU and the rest of the world (Eurostat 2019). Adopting this approach, net FDI outflows from the EU to the rest of the world (the so-called extra-EU) were negative, according to preliminary data, at EUR 60 billion. This contrasts strongly with the positive result from the previous year (EUR 301 billion) (Eurostat 2019). Divestments from the EU market made by foreign investors from outside the EU (i.e., from the rest of the world) were approximately EUR 205 billion. It was almost equal to the amount of FDI inflows to the EU from the rest of the world in 2017 (EUR 265 billion) (Eurostat 2019).

The main reason for the above situation was the already mentioned serious divestments between the US and the EU, caused by adverse changes in the investment climate (tax regulations in the USA). It is estimated that US companies withdrew almost EUR 177 billion of net direct investment from the EU market, causing a downward trend in FDI inflows to the EU. Similarly, EU companies withdrew from the US market, with a net divestment of EUR -165 billion (Eurostat 2019). As a result, Switzerland and Canada became the EU's main external partners in FDI capital flows. Therefore, observations of high volatility and instability of FDI capital flows between the EU as a grouping and the rest of the world can be confirmed based on Eurostat databases.

The FDI flows are affected by one-off large mergers and acquisitions or the withdrawal of significant investors motivated by their own risk assessments, as well as by investment climate changes, not only in the host countries but also in investor home countries. The 
EU member states must be ready to face rapidly changing and shrinking FDI flows. If the preliminary UNCTAD data for 2019 that indicate a further decline in FDI inflows to the EU by $15 \%$ are confirmed, it would mean a worsening of the EU's position in this respect (UNCTAD 2019, p. 1). Consequently, the question of the investment attractiveness of EU member states arises, especially compared to developing Asia.

In the context of deteriorating external relations in the sphere of FDI capital flows, intra-EU flows stimulated by the free movement of capital established within the framework of the single internal market are becoming increasingly important. In the case of the new EU member states, the inflows of FDI from other EU countries are dominant and decisive for their economies.

The European Union established the free movement of capital between member countries and in relations with third countries as a result of a long process to integrate the capital and financial markets of the EU member states. The current legal regulations are included in the Lisbon Treaty (TFEU 2012). The implementation of the Treaty allowed the free movement of capital within the grouping. It also liberalized the capital flows in relations with third countries, which allowed FDI flows to intensify.

\section{Actions to strengthen the position of the European Union in global capital flows}

The actions at the level of EU institutions taken in relation to foreign investors in a global context result from the extension of the EU's competence in this field. It refers to the common investment policy and its instruments, i.e., investment liberalization agreements and their protection in relations with third countries, investment dispute settlement methods, and screening FDI flowing into the EU.

\section{Common investment policy}

The entry into force of the Treaty on the Functioning of the European Union (Lisbon Treaty) changed the competences of EU institutions and member states concerning policy towards foreign investors. The Treaty gives the EU new competence in external relations, incorporating direct foreign investment in the common commercial policy (Art. 206), and it confirms the distribution of competences between the Union and the member states (Art. 207) (TFEU 2012).

The provisions of the Treaty are considered important, and they strengthen the EU's competences concerning external investments. However, at the same time, they are perceived as a "half-success" on the road to creating a common investment policy (Shan and Zhang 2010). However, according to some researchers, the way in which the provisions on the common investment policy were introduced into the Treaty on the Functioning of the European Union may negatively affect their implementa- 
tion (Meunier 2017, pp. 593-610). Transferring competences in the field of investment policy from the national level to the EU level did not take place as a result of intergovernmental negotiations or the pressure of interest groups. It even took place against the preferences of the member states. It was the result of a specific combination of the neo-functional approach of the European Commission and its use of the circumstances (other, more important priorities for member states as part of a comprehensive and tense negotiation agenda on the TFEU). The lack of negotiations during the formulation of Treaty provisions regarding the transfer of these competences to the EU level resulted in a political debate in the implementation phase of the regulations regarding the common investment policy (Meunier 2017, pp. 593-610).

The problems that appear in the context of establishing a common investment policy seem to confirm the above theses. Controversial issues and disputes are related to:

- ensuring national treatment at the stage preceding investing abroad, i.e., granting pre-investment guarantees; in the newly negotiated free trade agreements with Singapore (2015), Canada (2016), and Vietnam (2016), the EU received the above guarantees for investors; however, in case of any conflicts, the implementation of the EU approach will depend on the goodwill of governments to settle disputes within the state-to-state-dispute-settlement mechanisms;

- investment protection, including Investor-State-Dispute-Settlements - ISDS; EU proposals to set up an international investment court have not received support from global partners;

- the so-called mixed agreements, which are thus named as they have to be accepted by both the EU and the member states; the free trade agreement with Canada, which followed this procedure, is an example.

The provisions of the Lisbon Treaty, which changed the competences of the EU institutions and the member states concerning policy towards foreign investors, are first and foremost relevant to the functioning of the free flow of investment within the EU. The relations between the rights of individual member states and the European Union require ordering and defining, particularly concerning intra-EU investment protection issues and incentives used by member states. It is important to provide investors with a high level of protection while recognizing the right of the $\mathrm{EU}$ and the member states to regulate markets when justified by public interest. Both the EU and the member states have the right to take appropriate legal measures that may have a negative impact on investment, but only under certain conditions and following EU law (COM 2018, p. 1).

Since the shift of competence concerning foreign investment causes legal disputes, the European Court of Justice (CJEU) has an important role to play in determining the final shape of the EU investment policy. The CJEU is expected to express its opinion on the legality of future international investment agreements (IIAs), the issue of compatibility of the Investor-State Dispute Resolution System (ISDS) with the EU's legal order. It should also answer the question regarding the extent to which new generations of EU trade and investment agreements can directly confer rights on private entities (Herrmann 2014, pp. 570-584). 


\section{Investment agreements between the EU and third countries}

The EU has undertaken numerous negotiations on trade and investment agreements with external partners, which can be perceived as part of the implementation of investment policy. Concluded agreements and those currently being negotiated are either comprehensive cooperation agreements, which also include provisions regarding investments, or they are agreements aimed mainly at facilitating investments and their protection in mutual relations.

The agreement which is especially important for the broadening of the area of competence of the EU in relation to investment policy is The Comprehensive Economic and Trade Agreement (CETA) between Canada and the European Union, signed on October 28, 2016 (Umowa gospodarczo-handlowa..., n.d.). The provisions of the EU-Canada Agreement concerning the settling of disputes between investors and governments have been the subject of a CJEU ruling. This ruling sets a new standard in agreements currently being negotiated by the EU with other countries (CJEU, https://www.iisd.org/itn, accessed: 4.03.2020). The CETA provisions regarding investments relate to measures designed to increase investment flows between parties, protect investors, and ensure they are treated fairly by governments (Umowa gospodarczo-handlowa..., n.d.).

Another agreement that was important for clarifying the scope of the EU competence in investment policy is the free trade agreement with Singapore signed in October 2018, which entered into force on November 21, 2019 (Is there an EU-ASEAN..., 2019). According to the opinion of the CJEU 2/15 of May 16, 2017, on the EU competence to conclude an agreement with Singapore, the EU has exclusive power to determine the essential protection standards, usually included in investment protection agreements, concerning direct foreign investment. In contrast, the competence concerning portfolio investment and investor-to-state dispute resolution (ISDS) is one shared between the EU and the member states. All member states must ratify the investment protection agreement according to national procedures (EUR-LEX 2017; EC 2019a, p. 52; EC 2020).

Another agreement between the European Union and a developed country - a trade agreement with Japan - signed in July 2018 and adopted by the European Parliament, entered into force in February 2019. However, this agreement does not cover the issue of mutual investment. Negotiations on investment protection and investor-state dispute settlement are ongoing, but Japan does not accept the ICS solution (EC 2019a, p. 52; EC 2020, p. 2). At the same time, i.e., in June 2018, the European Union began negotiations with Australia and New Zealand on the conclusion of trade agreements. Future agreements will contain provisions on investment liberalization, while investment protection and investor-state dispute settlement issues are not negotiable (EC 2019a, p. 52; EC 2020, p. 4).

As part of relations with developed countries, in addition to the previously mentioned CETA agreement with Canada, the EU attempted to negotiate a comprehen- 
sive partnership agreement with the USA, i.e., the Transatlantic Trade and Investment Partnership (TTIP). This agreement aroused many controversies in the societies of EU member states; this concerned, in particular, investor protection and dispute resolution. After a change in the political situation in the USA, negotiations were suspended.

The negotiations between EU and China on the signing of the Comprehensive Agreement on Investment (CAI) were vital for improving the EU's investment position in developing Asia. The negotiations began in 2014. The parties agreed on the scope of the future agreement in 2016, and they concluded in principle the negotiations in December 2020 (EP 2021; EC 2021). This agreement would replace 26 existing bilateral agreements between EU member states and China (EC 2020, p. 9). The scope of the CAI goes beyond the typical investment protection agreement. The issues for investors' access to the market (the national treatment of investors before investing in the host country's economy) are also included (EP 2019a). The agreement is expected to create favorable conditions for mutual direct investment flows and to bring positive effects for their economies in the future.

In relations with the developing countries of Latin America, the most significant $\mathrm{EU}$ achievement was the negotiation of an association agreement with the Mercosur grouping. Regarding the commercial part, an agreement was reached on June 28, 2019. However, negotiations are currently underway on liberalizing investment between the two integration groupings (EC 2019a, p. 53; EC 2019b). The European Union has also taken steps to modernize agreements with Mexico and Chile.

An analysis of international agreements concluded by the EU in terms of their geographical scope indicates an apparent expansion of the EU in negotiating and concluding agreements with all important EU partners. This activity should also be seen as a means of improving the position of the whole EU and its member states in global capital flows. The EU is making this effort in its relations with both developed and developing countries. The substantive scope of this activity includes the modernization or extension of existing contracts, the conclusion of new free trade and cooperation agreements in the field of investment, comprehensive cooperation, or partnership.

\section{Settling disputes between investors and host countries}

The problem of settling disputes between investors and host countries (ISDS) is so vital that global organizations, just like the European Union, are trying to solve it. Although an agreement on TTIP was not concluded, the discussion on problems related to settling disputes in investor-state relations brought new initiatives aimed at addressing this issue at the EU level. The European Commission's proposal, announced in 2015, involved the creation of a dispute settlement system in the form of an Investment Court System (ICS) (EC 2015; EP 2017a). In principle, the new system would be used 
as a bilateral solution adopted in trade and investment agreements concluded by the EU on behalf of the member states.

The ICS organizational structure has two levels, i.e., the Tribunal, as the first instance, and the Appellate Tribunal, as the appeal instance. Unlike the system used in international arbitration, the parties will not be allowed to choose their arbitrators at the Tribunal. They will be selected on a rotational basis from a group of judges appointed by a joint committee established by a given agreement. The justification for starting the ICS procedure may be intentional discrimination of the investor on the grounds of sex, race, religion, nationality, expropriation without compensation, or refusal to grant justice. Moreover, the new system guarantees the governments of member states the right to introduce their regulations freely.

The ICS, proposed by the EU and introduced in the EU-Canada Agreement (CETA), can be seen as an attempt to create an arbitration system that is more transparent, convincing for societies, and safer for the member states. However, this proposal encountered strong social opposition (Menkes 2016, pp. 149-167; Witkowska 2017). In this case, the EU Court of Justice issued a binding opinion on June 27, 2019, recognizing that the inclusion of ICS provisions in the CETA agreement is compatible with EU law (CJEU 2019). The introduction of the new system should address social concerns regarding the right of member states to regulate.

The binding opinion of the CJEU on establishing a new investor-state dispute settlement system at the EU level can be seen as reaching the next stage in the implementation of the common investment policy within the EU. However, it is currently difficult to assess the impact of new systemic solutions on FDI flows within the EU and in relations with third countries. Over time, ICS practice will show whether public concerns about the limitations of member states' right to regulate or abstain from regulating these issues, which have involved ISDS international arbitration, will be dispelled. The development directions of the dispute resolution system at the global/international level also remain unresolved.

\section{Regulations on a common framework for screening foreign direct investment flowing into the EU}

The EU has taken action to establish a common framework for screening foreign direct investment flowing into the EU. Regulations regarding this issue entered into force in April 2019 (OJEU 2019). The general justification for the introduction of screening was the protection of the public interest in the context of the expansion of foreign investors from third countries in strategic EU sectors. The existing screening mechanisms in EU member states, implemented for reasons of national security, combined with procedures of checking the compliance of mergers and acquisitions with EU competition rules, were considered insufficient in a changing situation (EP 2017b, EP 2019). 
The changes in capital flows between the EU and the rest of the world have been taking place for two decades, indicating the growing interest of investors from emerging economies in investing in EU member countries. This trend would not yet constitute the basis for introducing a new EU investment policy instrument in the form of FDI screening if not for the observed changes in the sectoral structure of these investments. Foreign investors are interested in investments in the high-tech processing industry. Investors mainly focus on strategic technologies, infrastructure, resources, and sensitive information (COM 2017). Moreover, FDI inflows in the form of mergers and acquisitions increased while greenfield investments were six times lower. In existing legal conditions, foreign investors could, therefore, gain control and influence strategic sectors in the EU economy using mergers and acquisitions as a way to enter the EU market.

According to the new regulation, member states may maintain existing FDI screening mechanisms, ${ }^{1}$ change them, or adopt new mechanisms for reasons of security and public order (OJEU 2019). FDI screening is the sole responsibility of the member states. They have the exclusive right to decide on its mechanism and carry out the screening of individual investment projects. Countries that do not yet have such mechanisms are not obliged to implement them.

However, the EU regulation imposes basic common requirements concerning screening mechanisms and procedures carried out by member states, i.e., the principle of transparency of procedures, non-discrimination of investors, and the possibility of recourse against screening decisions. Measures are also required to prevent investors from circumventing applicable screening laws and decisions. The regulation introduces an indicative list of criteria that help the European Commission and member states determine whether a given FDI project may pose a threat to public security and order.

The monitoring procedure is not centralized, and the EU member states retain their competences in this respect. However, coordination mechanisms have been introduced between the European Commission and member states, including the obligation to exchange information between parties involved in the screening procedure, the obligation to clarify if the opinion of the Commission has not been taken into account, as well as the obligation to establish contact points by all EU member states and the Commission in order to implement the regulation.

Preliminary assessments of the potential effects of introducing the new regulation refer to the EU as a whole, individual countries, and third countries (Sunesen and Hansen 2018, pp. 42-44). It will result in additional administrative costs at the EU and member state level, while for foreign investors, it will involve adjustment costs and costs related to uncertainty and risk of investment delays. For some member states, this may result in limited access to capital, e.g., in the new EU member states.

1 Prior to the introduction of the EU regulation, 14 member countries had national FDI screening mechanisms, which differed in the manner and scope of functioning, cf.: EP 2019b. 
The new regulations, assessed in the context of the emergence of the Union's common investment policy, indicate that initial efforts have been made at the EU level to create a new instrument of this policy. This instrument is potentially restrictive. Its use should safeguard the vital strategic interests of the EU and member states in the global economy. The introduction of a new screening system under the EU investment policy also seems to admit that the introduction of free movement of capital in relations between the EU and third countries may pose serious problems.

\section{Conclusions}

The EU remains a net FDI investor in the global economy. However, in recent years, there has been a general decrease in the circulation of FDI capital between the EU and the rest of the world, as well as the high volatility and instability of FDI capital flows in the case of individual EU member states.

Compared to other major investors in the global economy, the EU is losing its investment position. The investment attractiveness of the EU member states turns out to be much smaller than that of developing Asia.

For individual countries, in the context of deteriorating external relations in the field of FDI capital flows, intra-EU flows stimulated by the free movement of capital within the single internal market are of growing importance.

The EU is trying to strengthen the grouping's investment position in the global economy using the common investment policy established by the Lisbon Treaty. The division of competences between the EU institutions and member states is still a matter of dispute and emerges as a result of rulings of the CJEU.

EU institutions use the opportunities offered by the common EU investment policy. These are the inclusion of the issue of guarantees for the EU investors in concluded investment agreements with third countries, i.e., ensuring national treatment before investing, solving the problem of protecting foreign investment, which includes settling disputes between investors and host countries (ISDS).

The EU also creates a common screening framework for foreign direct investment flowing into the EU to protect the EU economies against losing control over strategic sectors, technologies, resources, and information.

\section{References}

CJEU (2019), CJEU finds ICS in Canada - EU CETA to be in line with EU law, https:// www.iisd.org/itn/2019/06/27/cjeu-finds-ics-in-canada-eu-ceta-to-be-in-line-with -eu-law/ (accessed: 4.03.2020).

COM (2017), Commission Staff Working Document Accompanying the document Proposal for Regulation of the European Parliament and of the Council establishing 
a framework for screening of foreign direct investments into the European Union, European Commission, COM 2017487 final, Brussels SWD 297 final.

COM (2018), Communication from the Commission to the European Parliament and the Council, Protection of intra-EUinvestment, 547 final, Brussels, 19.07.2018.

Della Posta, P. (2018), The Economics of Globalization, Edizioni ETS, Pisa.

EC (2015), Commission Proposes New Investment Court System for TTIP and Other EU Trade and Investment Negotiations, https://ec.europa.eu/commission/presscor ner/detail/en/IP_15_5651 (accessed: 8.02.2021).

EC (2019a), Commission Staff Working Document on the Movement of Capital and the Freedom of Payments, Brussels, 27.02.2019, SWD 94 final.

EC (2019b), EU and Mercosur Reached Agreement on Trade, European Commission, Directorate-General for Trade, "News Archive", Brussels, 28.06.2019, https://trade .ec.europa.eu/doclib/press/index.cfm?id=2039 (accessed: 18.03.2020).

EC (2020), Overview of FTA and Other Trade Negotiations, Updated February 2020, European Commission, Commission Staff Working Document, https://trade.ec.eu ropa.eu/doclib/docs/2006/december/tradoc_118238.pdf (accessed: 21.03.2020).

EC (2021), EU and China reach agreement in principle on investment, https://trade.ec .europa.eu/doclib/press/index.cfm?id=2233 (accessed: 8.02.2021).

EP (2017a), Puccio, L., Harte R., From Arbitration to the Investment Court System (ICS). The Evolution of CETA Rules, In-Depth Analysis, European Parliament, EPRS/European Parliamentary Research Service, June 2017.

EP (2017b), European Parliamentary Research Service, Foreign direct investment screening. A debate in light of China - EU FDI flows, Briefing May 2017.

EP (2019), EU to scrutinize foreign direct investment more closely, Press Releases, Plenary Session, "News. European Parliament” https:/www.europarl.europa.eu/news /en/press-room/20190207IPR25209/eu-to-scrutinise-foreign-direct-investment-mo re-closely (accessed: 9.02.2021).

EP (2021), EU-China Comprehensive Agreement on Investment (EU-China CAI), Legislative Train Schedule, European Parliament, https://www.europarl.europa.eu/le gislative-train/theme-a-balanced-and-progressive-trade-policy-to-harness-global isation/file-eu-china-investment-agreement (accessed: 8.02.2021).

EUR_LEX (2017), Opinion 2/15 of The Court (Full Court) 16 May 2017, https://eurlex.eu ropa.eu/legal-content/EN/TXT/PDF/?uri=CELEX:62015CV0002(01)\&from=EN (accessed: 20.05.2020).

Eurostat (2019), EU Foreign Direct Investment Flows in 2018, 17.07.2019, https://ec .europa.eu/eurostat/web/products-eurostat-news/-/DDN-20190717-1 (accessed: 20.02.2020).

Herrmann, Ch. (2014), The Role of the Court of Justice of the European Union in the Emerging EU Investment Policy, "The Journal of World Investment \& Trade", 15 (3-4), pp. 570-584, https://doi.org/10.1163/22119000-01504011

Is there an EU-ASEAN Trade Deal on the Horizon? (2019), "ASEAN Today", https:// www.aseantoday.com/2019/12/is-there-an-eu-asean-trade-deal-on-the-horizon/ (accessed: 18.03.2020).

Menkes, J. (2016), Mechanizm rozstrzygania sporów inwestor-państwo i TTIP - polska perspektywa [Investor-State Dispute-Settlement and TTIP - Polish Prospects], [in:] 
E. Czarny, M. Słok-Wódkowska (eds.), Partnerstwo transatlantyckie. Wnioski dla Polski, PWE, Warszawa.

Meunier, S. (2017), Integration by Stealth: How the European Union Gained Competence over Foreign Direct Investment, "Journal of Common Market Studies", 55 (3), pp. 593-610, https://doi.org/10.1111/jcms.12528

OJEU (2019), Regulation (EU) 2019/452 of the European Parliament and the Council of March 19, 2019, establishing a framework for the screening of foreign direct investments into the Union, Official Journal of the European Union L 79 I, 21.03.2019.

Primo Braga, C.A. (2018), Foreign Direct Investment and "Peak Globalization", "Columbia FDI Perspectives”, 230, https://doi.org/10.2139/ssrn.3403051

Shan, W., Zhang, S. (2010), The Treaty of Lisbon: Half Way toward a Common Investment Policy, "The European Journal of International Law”, 21 (4), pp. 1049-1073, https://doi.org/10.1093/ejil/chq071

Sunesen, E.R., Hansen, M.M. (2018), Screening of FDI towards the EU, Copenhagen Economics, Danish Business Authority, Copenhagen.

TFUE (2012), Treaty of the functioning of the European Union (Consolidated version), "Official Journal of the European Union", C 326/47, 26.10.2012 PL.

Umowa gospodarczo-handlowa między Kanada a Unia Europejska [Comprehensive economic and trade agreement between the EU and Canada] (n.d.), https://eur-1 ex.europa.eu/legal-content/PL/TXT/HTML/?uri=LEGISSUM:4298972\&from=PL (accessed: 26.11.2020).

UNCTAD (2019), World Investment Report 2019. Special Economic Zones, Geneva 2019.

UNCTAD (2020), Global FDI Flows Flat in 2019. Moderate Increase Expected in 2020, "Investment Trends Monitor", January 20, 2020, 33.

UNCTAD database (a), https://unctadstat.unctad.org/wds/TableViewer/tableView.as px?ReportId=96740 (accessed: 27.04.2020).

UNCTAD database (b), https://unctadstat.unctad.org/wds/TableViewer/tableView.as px?ReportId=96740 (accessed: 13.02.2020).

Witkowska, J. (2017), Implications of the Transatlantic Trade and Investment Partnership (TTIP) for Investment Flows Between the European Union and the USA, "Comparative Economic Research. Central and Eastern Europe”, 20 (3), pp. 25-39, https:// doi.org/10.1515/cer-2017-0018

\section{Pozycja Unii Europejskiej w globalnych przepływach bezpośrednich inwestycji zagranicznych: instytucjonalne próby jej poprawy}

Globalne przepływy bezpośrednich inwestycji zagranicznych (BIZ) uległy w ostatnich latach spowolnieniu, a jego skutki są w szczególności odczuwane przez kraje rozwinięte, w tym przez Unię Europejską. Obserwowane jest generalne zmniejszenie cyrkulacji kapitału w formie BIZ w relacjach UE - reszta świata. Celem artykułu jest analiza zmian pozycji UE w globalnych bezpośrednich inwestycjach zagranicznych oraz ocena podejmowanych przez unijne instytucje wysiłków na rzecz poprawy tej pozycji. Unia Europejska wykorzystuje wspólną politykę inwestycyjną jako środek 
służący poprawie jej pozycji inwestycyjnej. Unia uzyskała kompetencje do prowadzenia tej polityki na podstawie Traktatu z Lizbony, ale jej rzeczywisty kształt ustalany jest w praktyce. Z punktu widzenia osiągania celu, jakim jest poprawa pozycji UE w globalnych przepływach FDI, istotne są umowy zawierane na szczeblu UE z innymi krajami i ugrupowaniami integracyjnymi, w sprawie inwestycji zagranicznych, zapewniające narodowe traktowanie inwestorów przed i po podjęciu inwestycji w krajach trzecich, rozwiązania stosowane dla ochrony inwestorów i rozwiązywania sporów między inwestorami a krajami przyjmującymi oraz stosowanie monitoringu projektów inwestycyjnych w celu ochrony strategicznych sektorów gospodarki UE. Polityka inwestycyjna UE może z jednej strony łagodzić skutki procesów spowolnienia przepływów BIZ, stwarzając korzystniejszy klimat dla inwestycji lokowanych za granica, a z drugiej strony chronić żywotne interesy gospodarcze UE w przypadku inwestycji napływających z krajów trzecich.

Słowa kluczowe: bezpośrednie inwestycje zagraniczne, Unia Europejska, polityka inwestycyjna 